Division of

Ophthalmology and Visual Sciences,

University Hospital, Queen's Medical Centre, Nottingham NG7 2UH, UK

A Joseph

H S Dua

A J King

Correspondence to: Professor H S Dua, Division of Ophthalmology and Visual Sciences, B Floor, Eye Ear,

Nose and Throat Centre,

University Hospital, Queen's

Medical Centre, Nottingham

NG7 2UH, UK

harminder.dua@,

Accepted for publication 4 April 2001

\title{
Failure of amniotic membrane transplantation in the treatment of acute ocular burns
}

\author{
Annie Joseph, Harminder S Dua, Anthony J King
}

Abstract membrane transplantation (AMT) for ocular surface reconstruction in patients with severe acute chemical and thermal burns.

Methods-Four eyes of three patients who suffered severe chemical $(n=3)$ and thermal $(n=1)$ burns were studied. The aim of AMT was to prevent symblepharon formation, promote conjunctival regeneration, inhibit corneal melting by promoting epithelialisation, and to protect the ocular surface while associated lid burns were treated. AMT was used to cover the entire ocular surface of all the severely burnt and ischaemic eyes, 2-3 weeks after the injury. Where indicated, AMT was repeated by itself or in combination with other procedures in all patients.

Results-Three of the four eyes developed symblepharon and progressive corneal melt requiring urgent tectonic keratoplasty. All four eyes had persistent epithelial defects. Less than $25 \%$ of conjunctival regeneration occurred in three eyes. Two eyes autoeviscerated, one patient underwent lid sparing exenteration for a painful blind eye and one eye became phthysical. Conclusions-AMT did not help to restore the ocular surface or preserve the integrity of the eye in all our patients with severe acute burns, when used by itself or in combination with other surgical procedures. This reflects the extreme severity of the ocular burns in these patients and, in turn, draws attention to the fact that the current classification system does not adequately reflect such severity. In the current system such burns would be grouped under grade IV injuries to the eye (more than $50 \%$ limbal ischaemia). The prognosis of patients with $100 \%$ limbal ischaemia is much worse than patients with just over $50 \%$ limbal ischaemia. This inadequacy of the classification system probably also explains the difference between outcomes of management of grade IV burns (with AMT) in this series, compared with others.

(Br f Ophthalmol 2001;85:1065-1069)
The management of chemical and thermal ocular burns has challenged ophthalmologists for more than 50 years. Treatment is aimed at promoting ocular surface epithelial recovery, augmenting corneal repair and controlling inflammation. ${ }^{1}$ Medical treatment for acute ocular burns include topical and systemic use of ascorbate, ${ }^{23}$ citrate, ${ }^{4}$ tetracycline, ${ }^{5}$ and steroids. ${ }^{6}$ Mild to moderate burns often show good
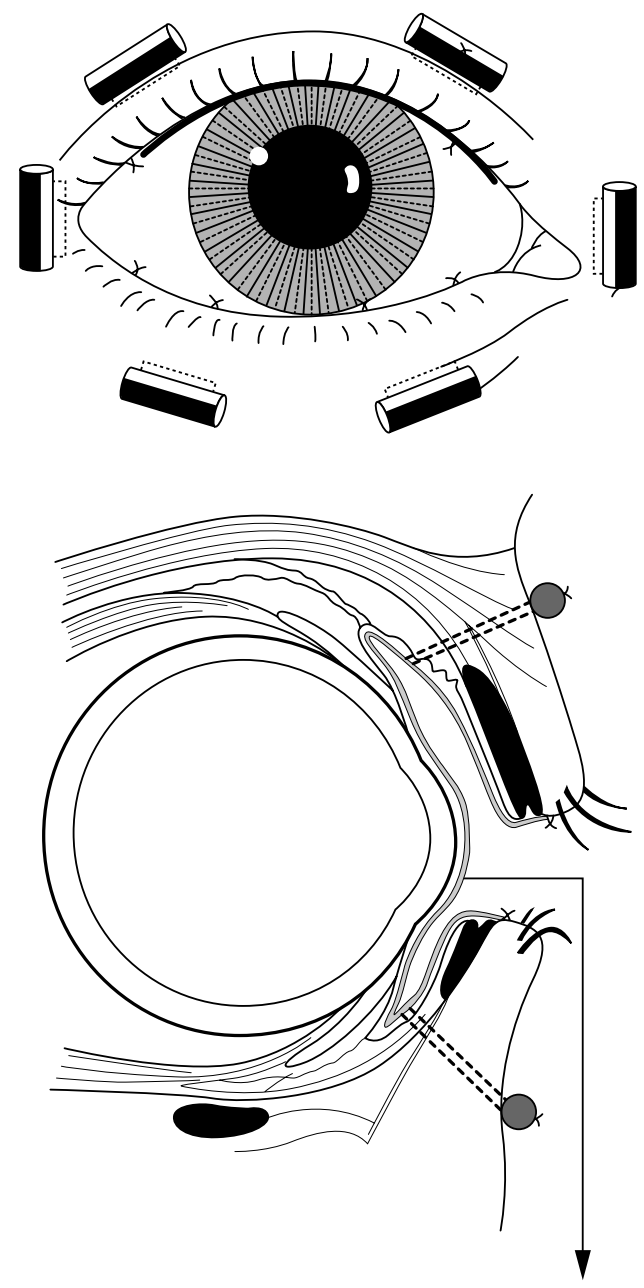

Amniotic membrane

Figure 1 Schematic diagram (above) showing double armed 4-0 silk fornix retaining sutures tied over bolsters, and 10-0 monofilament nylon sutures anchoring the amniotic membrane to the lid margins; (below) sagittal view showing amniotic membrane lining the entire ocular surface. 
response with medical therapy alone. The management of severe ocular burns is more complex as they are often associated with extensive lid burns and anterior segment ischaemia. Surgical intervention is invariably required, in spite of which the final visual prognosis is poor. ${ }^{7}$ Application of glued-on hard contact lens, ${ }^{8}$ tenoplasty, ${ }^{9}$ use of tissue adhesive, ${ }^{10}$ and large diameter keratoplasty ${ }^{11}$ are some of the surgical procedures used to salvage the acutely burnt eye.

Recently there have been several reports of successful treatment of ocular burns using amniotic membrane transplantation (AMT) with or without limbal cell transplantation. ${ }^{12} 13$ AMT alone was found to be sufficient to restore corneal and conjunctival surfaces in mild to moderate burns. ${ }^{12}$ In severe burns AMT restored the conjunctival surface without symblepharon and reduced limbal stromal inflammation, but did not prevent limbal stem cell deficiency, which required further limbal stem cell transplantation. ${ }^{12}$ While these results are encouraging, we have not been able to demonstrate similar success with AMT and limbal stem cell transplantation in our patients with very severe ocular burns. This may be because the widely used Roper-Hall classification of ocular burns allows for a broad range of injuries to be graded as severe or grade IV burns. ${ }^{14}$ With the advent of limbal cell transplantation and renewed interest in AMT a favourable outcome can be expected in patients with more than $50 \%$ limbal ischaemia if the conjunctiva is relatively spared. We report our experiences with four eyes of three patients who suffered extensive ocular burns, and discuss the need for a revision of the classification of ocular burns.

\section{Patients and methods}

Four eyes of three patients who underwent AMT as part of their treatment for very severe ocular burns were studied. One patient was assaulted with sulphuric acid and one was involved in a molten aluminium explosion, while the third sustained severe bilateral alkali burns when cleaning a drain. Two of the patients (cases 2 and 3) were secondary referrals to our centre, after initial treatment for their ocular, facial, and upper body burns.

Medical treatment of all patients included topical $10 \%$ ascorbate, $6 \%$ citrate, antibiotics, and steroids. The amniotic membrane was obtained and processed as described previously. ${ }^{15}$ Informed consent was obtained from all the patients. The amniotic membrane covered the entire ocular surface in all patients and was sutured to the limbus and lid margins with 10-0 monofilament nylon. Double armed 4-0 silk sutures were tied over the skin with bolsters to form the fornices (Fig 1). In all patients the amniotic membrane was sutured with the epithelial surface up and mesenchymal surface in contact with the eye. Following AMT, all patients were treated with topical antibiotics, steroids, and intensive lubrication. The demographics and clinical data of the patients are summarised in Table 1 .

\section{CASE 1}

A 45 year old man, who sustained severe molten aluminium burns to his left eye and lids, presented with extensive left upper and lower

Table 1 Demographics and clinical data

\begin{tabular}{|c|c|c|c|c|c|c|c|c|}
\hline $\begin{array}{l}\text { Patient } \\
\text { No }\end{array}$ & Sex/age & Agent/eye & Key findings & $\begin{array}{l}\text { Non-ocular } \\
\text { injuries }\end{array}$ & $\begin{array}{l}\text { Days between } \\
\text { injury and } \\
A M T\end{array}$ & Additional procedures & $\begin{array}{l}\text { Indication for additional } \\
\text { procedures }\end{array}$ & Outcome \\
\hline 1 & Male/45 & Thermal/L & $\begin{array}{l}\text { Lid burns, } 95 \% \\
\text { conjunctival loss, } 360^{\circ} \\
\text { limbal ischaemia, } \\
100 \% \text { ED with stromal } \\
\text { clouding, no iris } \\
\text { details, } 2^{\circ} \text { glaucoma }\end{array}$ & nil & 13 & $\begin{array}{l}\text { Lateral tarsorrhaphy } \\
\text { Vitreous biopsy } \\
\text { Upper lid reconstruction } \\
\text { Tectonic PK } \\
\text { Rpt AMT } \\
\text { Lat tarsorrhaphy } \\
\text { Buccal mucous memb graft to } \\
\text { lids }\end{array}$ & $\begin{array}{l}\text { Corneal exposure } \\
\text { To exclude endophthalmitis } \\
\text { Lid necrosis } \\
\text { Corneal perforation } \\
\text { Persistent epithelial defect } \\
\text { Corneal exposure } \\
\text { Poor lid closure }\end{array}$ & $\begin{array}{l}\text { Lid sparing } \\
\text { exenteration } \\
8 \text { months after } \\
\text { injury }\end{array}$ \\
\hline $2 \mathrm{a}$ & Male/65 & Alkali/R & $\begin{array}{l}\text { Lid burns, fixed globe, } \\
100 \% \text { conjunctival } \\
\text { loss, } 360^{\circ} \text { limbal } \\
\text { ischaemia, } 100 \% \mathrm{ED} \\
\text { with melting cornea, } \\
\text { flat AC, cataract }\end{array}$ & $\begin{array}{l}\text { Burns of } \\
\text { face, left } \\
\text { shoulder } \\
\text { and back }\end{array}$ & 8 & $\begin{array}{l}\text { Rpt AMT } \\
\text { Lamellar limbal corneal graft } \\
\text { with AMT } \\
\text { UL reconstruction } \\
\text { Aspiration of lens matter }\end{array}$ & $\begin{array}{l}\text { Persistent epithelial defect } \\
\text { Corneal melt } \\
\text { UL symblepharon } \\
\text { Swollen cataract }\end{array}$ & $\begin{array}{l}\text { Autoevisceration } \\
1 \text { year after } \\
\text { injury }\end{array}$ \\
\hline $2 b$ & Male/65 & Alkali/L & $\begin{array}{l}\text { Lid burns, fixed globe, } \\
100 \% \text { conjunctival } \\
\text { loss, } 360^{\circ} \text { limbal } \\
\text { ischaemia, } 100 \% \mathrm{ED} \\
\text { with melting cornea, } \\
\text { flat AC, cataract }\end{array}$ & $\begin{array}{l}\text { Burns of } \\
\text { face, left } \\
\text { shoulder } \\
\text { and back }\end{array}$ & 8 & Rpt AMT & Persistent epithelial defect & $\begin{array}{l}\text { Autoevisceration } \\
50 \text { days after } \\
\text { injury }\end{array}$ \\
\hline 3 & Male/40 & Acid/R & $\begin{array}{l}\text { Lid burns, } 100 \% \\
\text { conjunctival loss, } 360^{\circ} \\
\text { limbal ischaemia, } \\
100 \% \text { ED with stromal } \\
\text { clouding, cataract }\end{array}$ & $\begin{array}{l}\text { Burns of } \\
\text { scalp and } \\
\text { shoulders }\end{array}$ & 19 & $\begin{array}{l}\text { Tenoplasty } \\
\text { Keratolimbal allograft and AMT } \\
\text { Living related limbal allograft } \\
\text { LL symblepharon correction } \\
\text { Keratolimbal allograft and AMT } \\
\text { Tarsorrhaphy and entropion } \\
\text { surgery } \\
\text { Lamellar patch corneal graft } \\
\text { Large tectonic PK } \\
\text { Keratoprosthesis with } \\
\text { vitrectomy, RD surgery silicone } \\
\text { oil and replacement of graft }\end{array}$ & $\begin{array}{l}\text { Limbal ischaemia } \\
\text { Persistent epithelial defect } \\
\text { Persistent epithelial defect } \\
\text { Symblepharon and exposure } \\
\text { Persistent epithelial defect } \\
\text { Entropion and corneal } \\
\text { exposure } \\
\text { Corneal perforation } \\
\text { Corneal perforation } \\
\text { Retinal detachment }\end{array}$ & $\begin{array}{l}\text { Phthysis bulbi } 2 \\
\text { years after injury }\end{array}$ \\
\hline
\end{tabular}

$\mathrm{ED}=$ epithelial defect; $\mathrm{AC}=$ anterior chamber $\mathrm{PK}=$ penetrating keratoplasty $\mathrm{AMT}=$ amniotic membrane transplantation; $\mathrm{UL}=$ upper lid; $\mathrm{LL}=$ lower lid; $\mathrm{RD}=$ retinal detachment. 


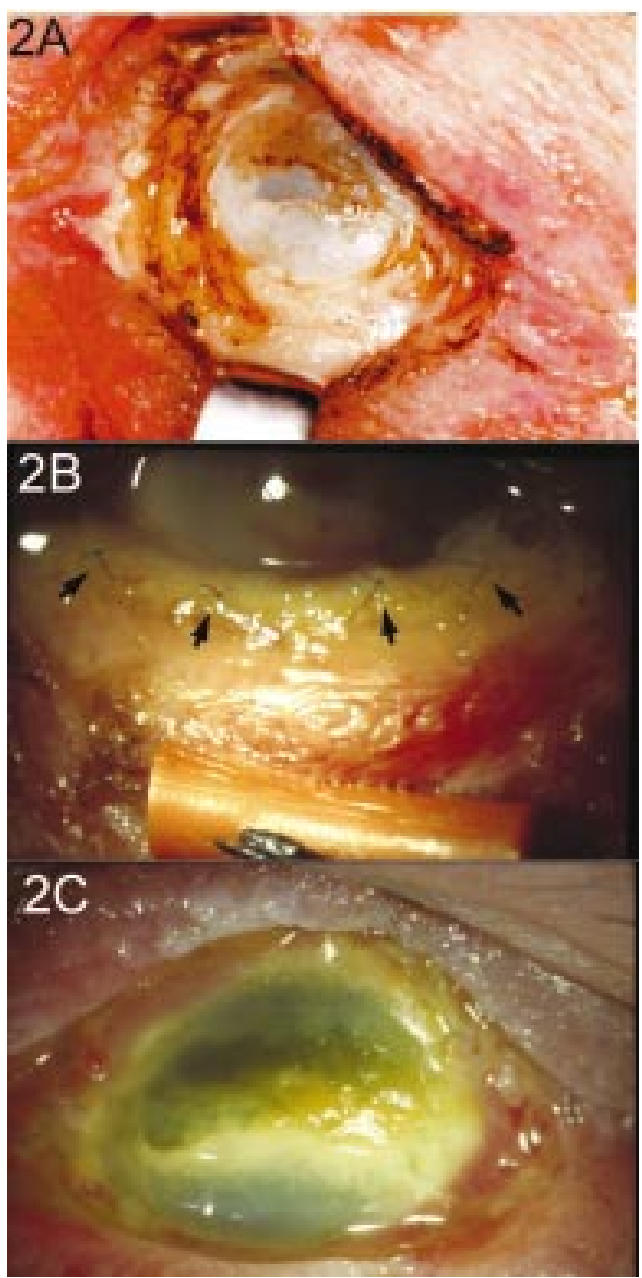

Figure 2 Clinical photograph of the left eye of case 1: $(A)$ few hours after the thermal burn showing lid burns, total limbal ischaemia, and opaque cornea; (B) demonstrating amniotic membrane sutured to the burnt oedematous lid margins (arrows) and the bolster over which the 4-0 silk suture is tied to form the lower fornix; $(C)$ demonstrating $360^{\circ}$ limbal ischaemia and necrotic cornea seen through the overlying amniotic membrane after the second AMT.

lid burns, almost total loss of bulbar and palpebral conjunctiva, 360 degree limbal ischaemia, total corneal epithelial cell loss with stromal oedema, and raised intraocular pressure (Fig 2A). There was no view of the anterior chamber. Visual acuity in the left eye was counting fingers. In addition to medical therapy, he underwent a left amniotic membrane graft and lateral tarsorrhaphy 13 days after the injury (Fig 2B). However, he developed progressive corneal melt with hypopyon, for which he had a vitreous biopsy with intravitreal antibiotics. There was no growth of organisms from the vitreous specimen, but he was treated with intensive antibiotics to cover a possible infection. He went on to develop necrosis of the left upper lid and perforation of the cornea. Left upper lid reconstruction and a tectonic sclerocorneal graft was performed. Intraoperatively he was found to have a left bullous choroidal/retinal detachment. Although the cornea was beginning to vascularise superiorly there was a large epithelial defect with considerable limbal ischaemia and incomplete lid closure. A second amniotic membrane graft and lateral tarsorrhaphy was performed to encourage healing of the epithelial defect (Fig 2C). Buccal mucous membrane was used to reconstruct the left lids to improve lid closure. However, he continued to develop total symblepharon and descemetocele in the left eye. Eight months after the injury he underwent left lid sparing exenteration for a painful blind eye.

CASE 2

A 65 year old man presented with extensive alkali burns to both eyes, face, and upper body. Visual acuities were perception of light in both eyes. He had bilateral lid burns, total limbal ischaemia, thin melting corneas, and cataracts. There was total loss of conjunctiva in both eyes and severe restriction of ocular movements in all directions. Initial treatment included topical ascorbate, citrate, steroids, and lubricants. As there was no clinical improvement he underwent bilateral amniotic membrane grafts 8 days after the injury.

On the left eye the graft remained in situ for about 3 weeks before disintegrating. There was minimal vascularisation of the conjunctiva at the medial canthus, but the rest of the eye remained ischaemic and the corneal thinning progressed. Two months after the injury the left eye autoeviscerated.

The right amniotic membrane transplant succeeded in preserving the integrity of the eye temporarily; but the conjunctiva remained ischaemic with severe corneal melt, requiring an urgent large limbal and corneal allograft with overlying amniotic membrane graft. $\mathrm{He}$ then developed upper lid symblepharon for which he underwent right upper lid reconstructive surgery. Four months after the large limbal corneal allograft, the lens was found to be swollen with a very shallow anterior chamber. Aspiration of lens matter with anterior vitrectomy was carried out. The corneal graft was cloudy and he continued to have 180 degree inferior limbal ischaemia with poor healing of the graft-host interface (Fig $3 \mathrm{~A})$. One year after the original injury, the graft-host interface broke down resulting in autoevisceration.

\section{CASE 3}

A 40 year old man suffered severe acid burns to both eyes, scalp, and shoulders. Both eyes suffered grade IV ocular burns, but the right eye was worse with lid burns, total conjunctival loss, $360^{\circ}$ limbal ischaemia, total corneal epithelial defect, thick cloudy stroma, and cataract. In addition to conventional medical treatment he was treated with topical citrate, autologous serum, ascorbic acid, and systemic steroids. He also underwent split skin grafting of the right upper and lower lid. Nineteen days after the injury, tenoplasty and AMT were performed. This resulted in minimal vascularisation of the conjunctiva but a large corneal epithelial defect persisted, necessitating a keratolimbal allograft with repeat AMT. Simultaneously, immunosuppression in the form of oral cyclosporin was started. There was still no improvement in the corneal epithelial defect; therefore a living related conjunctivolimbal 


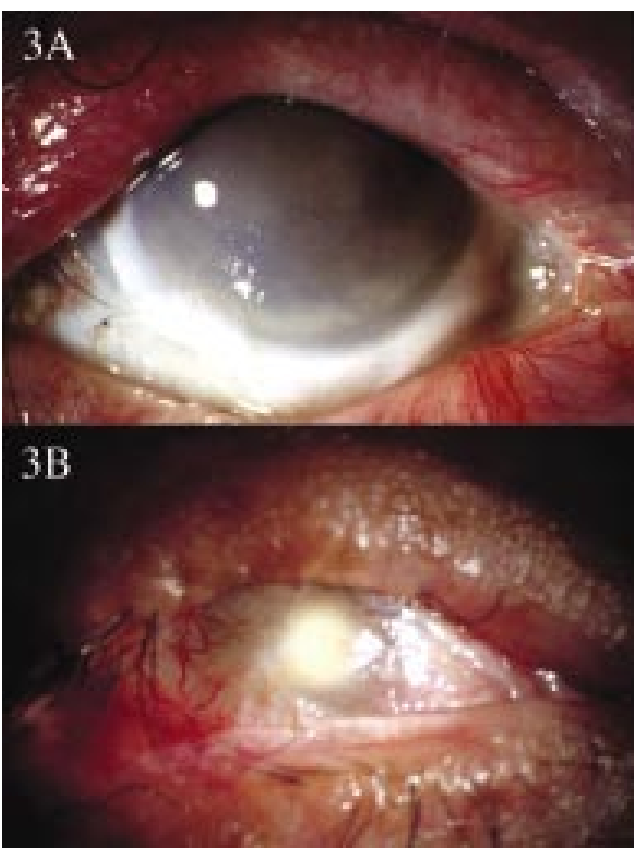

Figure 3 Clinical photographs $(A)$ of the right eye of case 2 few months after the large corneal graft and AMT; note the intense white colour of the ischaemic inferior limbus; $(B)$ the phthysical right eye of case 3,2 years after the injury.

allograft and lateral tarsorrhaphy were performed, after resection of the initial allograft. The corneal epithelial defect improved, but a persistent inferior defect remained and he developed symblepharon of the lower lid. Symblepharon division, inferior keratolimbal allografting, and AMT were repeated, but development of upper lid entropion and incomplete lid closure prevented healing of the epithelial defect. Though the entropion was surgically corrected, progressive corneal melt and perforation ensued, requiring an initial lamellar patch graft followed by a large penetrating tectonic keratoplasty with lens extraction, excision of iris, and anterior vitrectomy. The patient went on to develop a retinal detachment and underwent repeat sclerocorneal graft, vitrectomy, and intraocular silicone oil injection. Two years after the injury the eye was phthysical with a persistent epithelial defect (Fig 3B).

\section{Discussion}

In our patients AMT failed to re-establish the ocular surface when used by itself and in combination with other surgical procedures. All our patients had very severe ocular and lid burns. In the acute stage of these burns the primary goal is preservation of the globe. The continued absence of epithelium from both the conjunctiva and cornea along with limbal ischaemia encourages corneal melt and sterile ulceration due to enzymatic destruction of tissue. Associated lid burns, as were present in all our cases, further compound the problem and influence prognosis. Lid shortening, rigidity, and contractures cause exposure keratitis and mechanical injury to the cornea. The most important strategy of managing these burns in the acute stage is to reduce inflammation, promote vascularisation of the ischaemic ocular surface, and epithelialisation of the cornea.
Tenoplasty has been found to be effective in ensuring initial stabilisation of eyes with grade IV injuries. ${ }^{16}$ We were able perform tenoplasty in only one of our patients, as the extent of lid and ocular burns was too severe to attempt adequate tenoplasty in the others. We combined tenoplasty with AMT, but it failed to establish vascularisation of the ischaemic eye. Shimazaki et al reported successful reconstruction of the ocular surface with AMT in seven eyes with severe chemical and thermal burns. ${ }^{13}$ With the exception of one patient, AMT was performed more than 8 months after the injury when the survival of the globe had already been established. Mellor et al recently reported that AMT alone was effective in reducing limbal stromal inflammation, restoring the conjunctival surface and preventing symblepharon formation in six patients with grade IV burns. ${ }^{12}$ However, they also observed that the use of AMT for severe burns was limited due to the presence of deep stromal "ischaemia." All the patients in Mellor's series had some amount of intact conjunctival tissue at presentation and had AMT within 7-15 days after the injury.

In severe ocular burns, the combined loss of limbal blood supply, inflammation, and lack of vascularly derived collagenase inhibitors may result in anterior segment necrosis and sterile corneal ulceration at an early stage after the injury. An intact epithelium effectively arrests sterile corneal ulceration. ${ }^{16}$ The amniotic membrane promotes epithelialisation by several mechanisms. It provides a healthy basement substrate for the epithelium to grow. ${ }^{15} \mathrm{It}$ has been shown in vitro to produce various growth factors such as basic fibroblast growth factor, hepatocyte growth factor, and transforming growth factor $\beta$, that can stimulate epithelialisation. ${ }^{17}{ }^{18}$ Amniotic membrane has also been shown to promote healing in acute alkali burns in rabbits by inhibiting proteinase activity and polymorphonuclear leucocyte infiltration. $^{19}$ AMT is believed to promote epithelialisation by expanding the remaining epithelial stem cells. ${ }^{12}$ However, in very severe ocular burns involving $360^{\circ}$ of the limbus and almost the entire conjunctiva, there is probably a complete loss of epithelial stem cells. This may be one of the reasons why AMT was not successful in our patients. Three of our cases combined AMT with a source of epithelial stem cells as in a limbal corneal graft or a limbal cell transplant, but it failed to restore the ocular surface. Rao et al reported a similar failure of limbal autografting following acute grade IV alkali burns. ${ }^{20}$ The antifibroblastic effect of amniotic membrane has been used to explain the relatively low incidence of symblepharon formation when AMT was performed in the acute stage of ocular burns. ${ }^{12}$ Three of our cases developed symblepharon in spite of repeated AMT and mucous membrane graft to the lids. This could be because of the severe extent of initial conjunctival loss and lid burns in our patients.

In our patients AMT was not found to be useful in the restoration of the ocular surface in grade IV burns. This contrasts with the series reported by Mellor, where all the patients had 
a relatively favourable outcome. ${ }^{12}$ One of the issues to be addressed in this context is the grading of the severity of ocular burns. According to the Roper-Hall classification, grade IV includes all burns with more than $50 \%$ limbal ischaemia associated with opaque cornea and automatically implies a poor prognosis. ${ }^{14} \mathrm{How}-$ ever, the understanding of the concept of limbal stem cells and the advent of limbal cell transplant and AMT have helped to restore sight in eyes with more than 50\% limbal ischaemia. ${ }^{12}$ Dua and Augusto have reported the use of a modified classification system that takes into account clock hours of limbal involvement together with extent of conjunctival involvement. ${ }^{15}$ Current experience indicates that a "grade IV" with 55\% limbal ischaemia has a better prognosis than a "grade IV" with 90-100\% limbal ischaemia. Such differences in the probable outcomes of the Roper-Hall grade IV injury possibly explain the difference in outcomes of "grade IV" injuries being reported in the literature. A classification of ocular burns that takes into account the exact degree of limbal ischaemia and the extent of conjunctival and lid injury would enable more efficient comparison of results of the present day intervention strategies. It would also enable more accurate prediction of the prognosis in these patients. In conclusion, our experiences demonstrate the failure of AMT in restoring the ocular surface in very severe ocular burns, and emphasise the need for an updated classification of ocular burns.

1 Wagoner MD. Chemical injuries of the eye: current concepts in pathophysiology and therapy [review]. Surv Ophthalmol 1997;41:275-313.

2 Pfister RR, Haddox JL, Lank KM. Citrate or ascorbate citrate treatment of established corneal ulcers in the alkali-injured rabbit eye. Invest Ophthalmol Vis Sci 1988;29: $1110-5$.
3 Pfister RR, Paterson CA. Ascorbic acid in the treatment of alkali burns of the eye. Ophthalmology 1980;87:1050-7.

4 Pfister RR, Haddox JL, Paterson CA. The efficacy of sodium citrate in the treatment of severe alkali burns of the eye is influenced by the route of administration. Cornea 1982;1:205-11.

5 Seedor JA, Perry HD, McNamara TF, et al. Systemic tetracycline treatment of alkali-induced corneal ulceration in rabbits. Arch Ophthalmol 1987;105:268-71.

6 Donshik PC, Berman MB, Dohlman CH, et al. Effect of topical corticosteroids on ulceration in alkali-burned corneas. Arch Ophthalmol 1978;96:2117-20.

7 Kuckelkorn R, Makropoulos W, Kotteck A, et al. Retrospective study of severe alkali burns of the eyes. Klin Monatsbl Augenheilkd 1993;203:397-402.

8 Kenyon KR, Berman M, Rose J, et al. Prevention of stromal ulceration in the alkali-burned rabbit cornea by glued on contact lens. Evidence for the role of polymorphonuclear leukocytes in collagen degradation. Invest Ophthalmol Vis Sci 1979;18:570-87.

9 Teping C, Reim M. Tenoplasty as a new surgical principle in the early treatment of the most severe chemical eye burns. Klin Monatsbl Augenheilkd 1989; 194:1-5.

10 Fogle JA, Kenyon KR, Foster CS. Tissue adhesive arrests stromal melting in the human cornea. Am $\mathcal{F}$ Ophthalmol 980;89:795-802.

11 Redbrake C, Buchal V, Reim M. Keratoplasty with a scleral rim after most severe eye burns. Klin Monatsbl Augenheilkd 1996;208:145-51.

12 Mellor D, Renato TF, Pires, et al. Amniotic membrane transplantation for acute chemical or thermal burns. Ophthalmology 2000;107:980-90.

13 Shimazaki J, Hao-Yung Yang, Kazuo Tsubota. Amniotic membrane transplantation for ocular surface reconstrucmembrane transplantation for ocular surface reconstrucmology 1997;104:2068-76.

14 Roper-Hall MJ. Thermal and chemical burns. Trans Ophthalmol Soc UK 1965;85:631-40.

15 Dua HS, Azuara-Blanco A. Amniotic membrane transplantation. Br f Ophthalmol 1999;83:748-52.

16 Kenyon KR. Decision making in the therapy of external eye disease: non-infected corneal ulcers. Ophthalmology 1982; 89:44-51.

17 Shimazaki J, Shinozaki N, Tsubota K. Transplantation of amniotic membrane and limbal autograft for patients with recurrent pterygium associated with symblepharon. $\mathrm{Br} f$ Ophthalmol 1998;82:235-40.

18 Sato H, Shimazaki N, et al. Role of growth factors for ocular surface reconstruction after amniotic membrane transplansurface reconstruction after amniotic membran
tation. Invest Ophthalmol Vis Sci 1998;39:S428

19 Kim JS, Kim JC, Na BK, Jeong JM, et al. Amniotic membrane patching promotes healing and inhibits proteinase activity on wound healing following acute alkali burn. Exp Eye Res 2000;70:329-37.

20 Rao SK, Rajagopal R, Sitalakshmi G, et al. Limbal autografting: comparison of results in the acute and chronic phases of ocular surface burns. Cornea 1999;18: $164-71$. 